\title{
PROFIL HAMBATAN BELAJAR EPISTIMOLOGIS SISWA KELAS VIII SMP TERHADAP MATERI ENERGI DAN PERUBAHANNYA BERBASIS ANALISIS TES KEMAMPUAN RESPONDEN
}

\author{
Yunia Maghfirah $^{\text {a) }}$, Heni Rusnayatib), A. F. C. Wijaya ${ }^{\text {c) }}$ \\ Departemen Pendidikan Fisika, Fakultas Pendidikan Matematika dan Ilmu Pengetahuan Alam, Universitas \\ Pendidikan Indonesia, Jl. Dr. Setiabudi No. 229, Bandung 40154 \\ Email: a)yuniamaghfirah@gmail.com, b)heni@upi.edu, c)agus.fany@gmail.com
}

\begin{abstract}
Abstrak
Berdasarkan hasil studi pendahuluan melalui angket, tes, dan wawancara diketahui bahwa 52,12\% siswa mengalami hambatan belajar epistimologis pada materi energi dan perubahannya yaitu hambatan yang dialami siswa disebabkan karena keterbatasan konteks dalam memahami suatu konsep, dan lebih dari $50 \%$ siswa tidak mampu mengerjakan tes pada materi energi dan perubahannya. Tujuan dari penelitian ini adalah untuk mengetahui hambatan belajar epistimologis pada siswa kelas VIII SMP pada materi energi dan perubahannya berdasarkan hasil analisis Tes Kemampuan Responden. Penelitian ini dilakukan dengan menggunakan metode kualitatif deskriptif dengan analisis pendekatan historis menggunakan Tes Kemampuan Responden (TKR) yang berupa tes tertulis uraian yang terdiri atas lima soal yang mencakup materi esensial energi dan perubahannya yang diberikan pada siswa yang telah mempelajari materi energi dan perubahannya di salah satu SMP Negeri di Kabupaten Bandung Barat. Hasil penelitian menunjukkan bahwa 83,3\% siswa mengalami hambatan dalam menentukan hubungan antara kecepatan dengan energi kinetik, 86,11\% mengalami hambatan dalam menentukan hubungan antara ketinggian dan energi potensial, $100 \%$ siswa mengalami hambatan dalam menentukan jumlah energi yang dihasilkan dibandingkan energi yang digunakan pada konsep perubahan energi, serta 88,89\% siswa mengalami hambatan dalam menerapkan konsep kekekalan energi mekanik pada kasus gerak jatuh bebas.
\end{abstract}

Kata-kata kunci: hambatan belajar, tes kemampuan responden, energi dan perubahannya.

\begin{abstract}
Based on preliminary studies through questionnaire, test, and interviews, known that 52,12\% students have been experiencing epistemological learning obstacles on energy and its transformation subject which is due to the limited context in comprehending a concept, and more than 50\% students haven't able yet in doing the task with energy and its transformations. The objective of this study is to acknowledge the epistemological learning obstacles in 8th grade students on energy and its transformation subject based on respondents ability test analysis results. This study held with a qualitative descriptive method with historical approach analysis using respondents ability test which is a written essay test consists of five questions that cover energy and its transformation essential matter which were given to the students who had learned about energy and its transformation in one of public junior high school in Bandung Barat Regency. The result shows that 83,3\% students experienced obstacles in determining the relation between velocity and kinetic energy, $86,11 \%$ in determining the relation between height and potential energy, $100 \%$ in determining the amount of produced energy compared to used energy in energy transformation concept, also 88,89\% in applying the concept of conservation of energy in free fall motion case.
\end{abstract}


Keywords: learning obstacles, respondents ability test, energy and its transformation.

\section{PENDAHULUAN}

Permendikbud RI Nomor 103 Tahun 2014 tentang Pembelajaran pada Pendidikan Dasar dan Pendidikan Menengah menyatakan bahwa, proses pembelajaran diselenggarakan secara interaktif, menyenangkan, menantang, inspiratif, memotivasi peserta didik untuk berpartisipasi aktif, serta memberikan ruang yang cukup bagi prakarsa, kreativitas, dan kemandirian sesuai dengan bakat, minat, kemampuan, dan perkembangan fisik serta psikologis peserta didik. Menurut Basiran (2012) setiap siswa berhak memperoleh pengajaran yang memuaskan. Namun pada kenyataannya setiap siswa memiliki kebutuhan dan kemampuan yang berbeda-beda. Basiran (2012) menyatakan bahwa perbedaan individual inilah yang menyebabkan adanya perbedaan tingkah laku belajar siswa sehingga siswa tidak dapat belajar sebagaimana mestinya.

Lebih jauh lagi, pembelajaran yang diberikan pada siswa tidak dapat memenuhi kebutuhan siswa sehingga siswa akan mengalami hambatan dalam mengikuti kegiatan pembelajaran. Hambatan belajar adalah kesalahan yang tidak tentu dan tidak diharapkan. Kesalahan ini dapat berupa akibat dari pengetahuan siswa yang menurutnya menarik dan benar sekarang terbukti salah atau tidak dapat diterima dengan mudah. Dalam bukunya yang berjudul Theory of Didactical Situation, Brousseau (2002, hal.86) membagi sumber permasalahan hambatan belajar menjadi tiga, yaitu ontogenik, sumber didaktis, dan sumber epistemologi.

Brousseau (2002) menyatakan bahwa hambatan belajar epistemologi muncul sebagai pengetahuan yang belum utuh dan hambatan belajar epistemologi cenderung pada kesalahan yang dilakukan akibat hambatan yang ada dalam pengetahuan yang sedang dipelajari. Masih menurut Brousseau (2002) untuk dapat menentukan hambatan belajar epistemologi yang terjadi dapat dilakukan analisis pendekatan historis. Dalam bukunya yang berjudul Theory of Didactical Situation, Brousseau (2002, hal 101) memaparkan analisis pendekatan historis adalah analisis dengan menggunakan pertanyaan agar dapat yang melihat bagaimana siswa;

a. Menggambarkan pengetahuan yang dipelajari dan memahami penggunaannya,

b. Menjelaskan manfaat dari penggunaan pengetahuan yang telah dipelajari,

c. Melihat hubungan dari suatu konsep dengan konsep yang lain, untuk memahami keterbatasan dan kesulitan siswa pada konsep tersebut sehingga akhirnya dapat menemukan penyebab kegagalan konsep tersebut,

d. Mengidentifikasi suatu keadaan permasalahan dan memberikan alasan atas penyelesaian yang diberikan,

e. Mengulangi respon yang salah pada permasalahan yang sama persis atau mirip, serta bagaimana siswa memahami setiap permasalahan tersebut.

Berdasarkan hasil studi pendahuluan melalui angket dan wawancara siswa dan guru, diketahui bahwa 37,5\% siswa mengalami hambatan pada materi energi dan perubahannya, dimana 52,12\% siswa mengalami hambatan belajar epistimologi yakni hambatan yang dialami siswa karena keterbatasan konteks dalam memahami suatu konsep. Dari hasil tes tertulis yang diberikan juga diperoleh data bahwa 53,12\% siswa keliru menentukkan energi yang dimiliki benda dan perubahan energi pada fenomena fisis, serta 50\% siswa tidak dapat menentukkan kecepatan benda berdasarkan energi kinetik yang dimilikinya. Tujuan dari penelitian ini adalah untuk mengetahui hambatan epistimologis siswa kelas VIII pada materi energi dan perubahannya.

\section{METODE PENELITIAN}

Metode yang digunakan dalam penelitian ini adalah metode kualitatif deskriptif dengan analisis pendekatan historis sesuai yang diungkapkan Brousseau dalam bukunya Theory of Didactical Situation (2002, hal 101) menggunakan Tes Kemampuan Responden (TKR) yang berupa tes tertulis uraian yang terdiri atas lima soal yang mencakup materi esensial energi dan perubahannya. Tes 
Kemampuan Responden (TKR) diberikan pada siswa yang telah mempelajari materi energi dan perubahannya. Penelitian ini dilakukan pada siswa yang telah mempelajari materi energi dan perubahannya di salah satu SMP Negeri di Kabupaten Bandung Barat.

\section{HASIL DAN PEMBAHASAN}

Berikut merupakan hasil persentasi hambatan epistimologis peserta didik pada konsep-konsep esensial pada materi energi dan perubahannya berdasarkan jawaban Tes Kemampuan Responden (TKR) awal yang diujikan pada peserta didik yang pernah belajar materi energi dan perubahannya.

\section{Energi Kinetik}

Pada soal nomor 1, siswa diperlihatkan data dengan massa dan energi kinetik tiga buah mobil mainan, sebagai berikut;

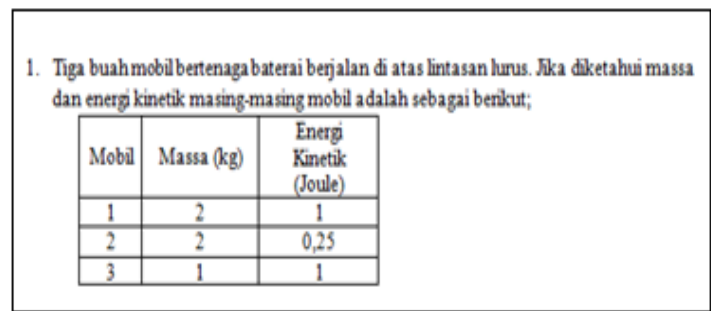

GAMBAR 1. Soal Uji TKR Nomor 1.

Soal ini merupakan adaptasi dari hasil studi pendahuluan dimana siswa tidak dapat menentukan hubungan antara kecepatan dan energi kinetik, dan tidak mampu menentukan kecepatan menggunakan persamaan energi kinetik.

Pada soal nomor 1a, siswa diminta mengurutkan besar kecepatan mobil dari yang terbesar hingga yang terkecil, namun banyak siswa tidak mampu menjawab soal nomor 1a dengan tepat karena siswa tersebut tidak mampu menentukan hubungan massa dan energi kinetik benda terhadap kecepatannya. Hal tersebut dibuktikan dengan hasil jawaban siswa pada soal nomor 1c dimana siswa diminta menjelaskan faktor yang mempengaruhi kecepatan mobil dan bagaimana pengaruhnya.

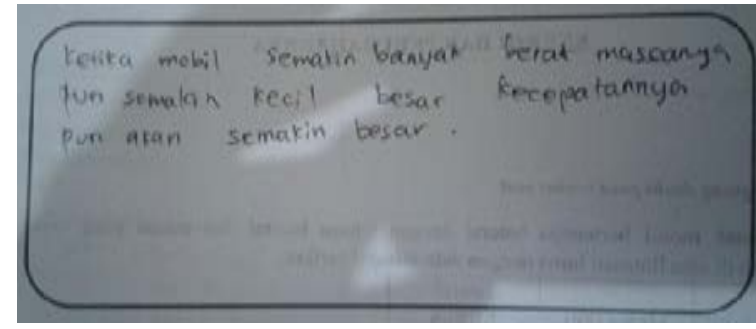

GAMBAR 2. Jawaban siswa pada soal nomor 1c.

Gambar 2 menunjukkan jawaban siswa yang tidak mampu menjelaskan hubungan energi kinetik dengan kecepatan. Berdasarkan hasil analisis jawaban TKR awal, diperoleh persentase hambatan epistimologis siswa pada konsep energi kinetik sebagai berikut; 
TABEL 1. Hambatan awal peserta didik pada konsep energi kinetik.

\begin{tabular}{|c|c|c|}
\hline Coding & Hambatan & Persentase TKR Awal \\
\hline 1. & $\begin{array}{l}\text { Tidak mampu mengoperasikan } \\
\text { persamaan energi kinetik untuk } \\
\text { menghitung kecepatan benda }\end{array}$ & $38,89 \%$ \\
\hline \multirow[t]{2}{*}{2.} & $\begin{array}{l}\text { a) Tidak mampu menjelaskan } \\
\text { kecepatan dengan energi } \\
\text { kinetik }\end{array}$ & $83,33 \%$ \\
\hline & $\begin{array}{l}\text { b) Tidak mampu menjelaskan } \\
\text { hubungan massa dengan } \\
\text { kecepatan }\end{array}$ & $75 \%$ \\
\hline
\end{tabular}

Berdasarkan hasil wawancara pada siswa, ketidakmampuan menjawab soal nomor 1c ini adalah karena siswa tidak dapat memaknai konsep fisis dari energi kinetik itu sendiri.

\section{Energi Potensial}

Pada soal nomor 2 siswa diberikan gambar tiga buah bola dengan ketinggian dan massa berbeda, sebagai berikut;

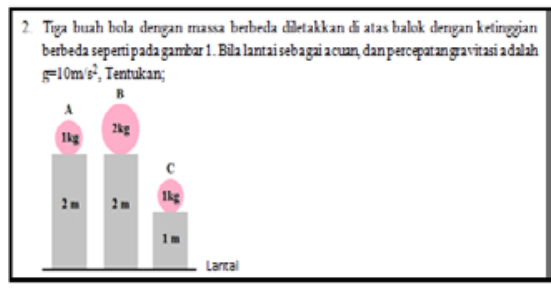

GAMBAR 3. Soal Uji TKR Nomor 2.

Soal ini diadaptasi dari soal-soal ulangan harian siswa untuk menghitung energi potensial benda. Pada soal nomor 2a siswa diminta mengurutkan besar energi potensial yang dimiliki bola $\mathrm{A}, \mathrm{B}$, dan $\mathrm{C}$ dari yang terbesar sampai yang terkecil, dan pada soal nomor $2 \mathrm{~b}$ siswa diminta menghitung besar energi potensial yang dimiliki masing-masing bola. Sebagian besar siswa menjawab soal nomor $2 \mathrm{~b}$ terlebih dahulu untuk menjawab soal nomor 2a. Hal tersebut terjadi karena siswa tidak mampu memahami pengaruh dari ketinggian dan massa terhadap energi potensial benda. Ketidakmampuan siswa tersebut terbukti dari hasil TKR jawaban siswa pada soal nomor 2c dimana siswa diminta menjelaskan faktor yang mempengaruhi energi potensial benda dan bagaimana pengaruhnya.

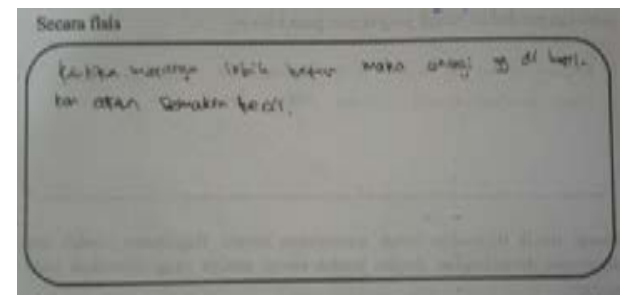

GAMBAR 4. Jawaban siswa pada soal nomor 2c.

Gambar 4 menunjukkan salah satu jawaban siswa yang tidak mampu menjelaskan pengaruh dari ketinggian dan massa terhadap energi potensial benda. Dari hasil TKR diketahui bahwa sebagian besar siswa tidak mampu menjelaskan hubungan massa, ketinggian, dan energi potensial. Berdasarkan hasil analisis jawaban TKR awal, diperoleh persentase hambatan epistimologis siswa pada konsep energi potensial sebagai berikut; 
TABEL 2. Hambatan awal peserta didik pada konsep energi potensial.

\begin{tabular}{ccc}
\hline Coding & \multicolumn{1}{c}{ Hambatan } & Persentase TKR Awal \\
\hline 1. & a) & $\begin{array}{l}\text { Tidak dapat menjelaskan } \\
\text { hubungan energi potensial } \\
\text { dengan ketinggian }\end{array}$ \\
& b) $\begin{array}{l}\text { Tidak dapat menjelaskan } \\
\text { hubungan energi potensial } \\
\text { dengan massa yang } \\
\text { dimiliki benda. }\end{array}$ \\
\hline
\end{tabular}

Pada gambar 4 selain keliru dalam menentukan hubungan massa dan energi potensial, siswa tersebut juga keliru dalam memahami konsep energi potensial yang sebenarnya dimiliki benda karena posisinya bukan dihasilkan benda karena massanya. Maka diketahui bahwa ketidakmampuan tersebut disebabkan karena siswa tidak mampu memaknai konsep fisis dari energi potensial itu sendiri.

\section{Energi Mekanik}

Pada soal nomor 3 siswa diberi soal penerapan konsep kekekalan energi mekanik pada kasus benda jatuh bebas, soal ini diadaptasi dari soal Ujian Nasional IPA SMP tahun 2016, No. 12 seperti berikut;

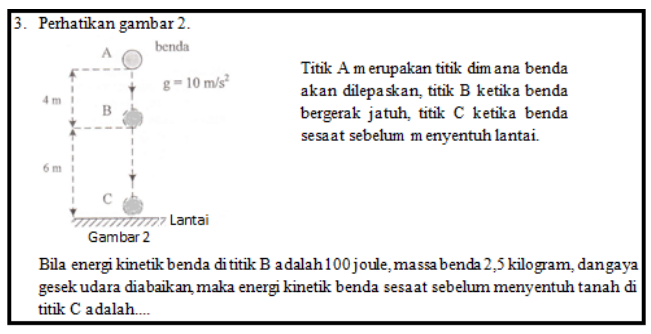

GAMBAR 5. Soal Uji TKR Nomor 3.

Berdasarkan hasil analisis jawaban TKR awal, diperoleh persentase hambatan epistimologis siswa pada konsep energi mekanik sebagai berikut;

TABEL 3. Hambatan awal peserta didik pada konsep kekekalan energi mekanik.

\begin{tabular}{ccc}
\hline Coding & \multicolumn{1}{c}{ Hambatan } & Persentase TKR Awal \\
\hline 1. & a) & Tidak mampu \\
& menyebutkan besaran yang & \\
& dibutuhkan untuk \\
& menyelesaikan \\
& permasalahan pada konsep \\
& kekekalan energi mekanik. \\
& beliru menentukan besaran & \\
& yang dibutuhkan untuk & \\
& menyelesaikan \\
& permasalahan pada konsep \\
& kekekalan energi mekanik. & \\
& Tidak mampu menerapkan \\
persamaan kekekalan energi & \\
mekanik pada kasus gerak jatuh & \\
& bebas \\
\hline
\end{tabular}


Berikut merupakan salah satu contoh jawaban siswa pada soal nomor 3;

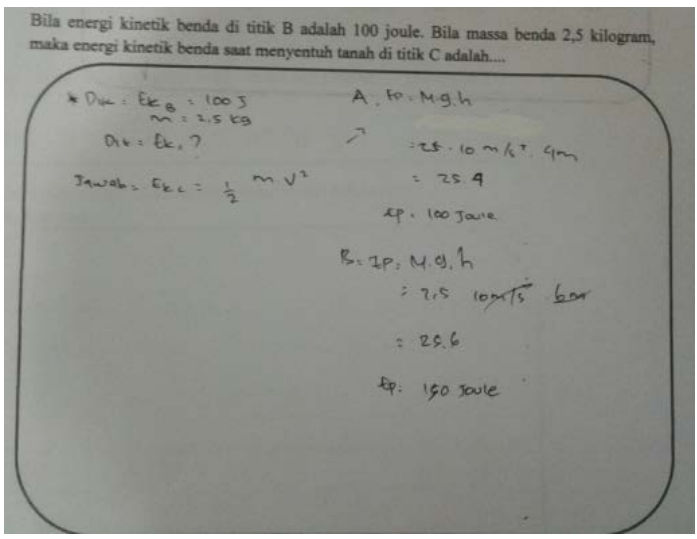

GAMBAR 6. Jawaban siswa pada soal nomor 3.

Gambar 6 menunjukkan siswa keliru mengidentifikasi besaran pada soal yaitu menentukan ketinggian bola di A adalah 4 meter. Kekeliruan siswa ini terjadi karena siswa tidak dapat memaknai besaran fisis pada soal dan siswa tidak memahami bahwa pengukuran ketinggian benda harus berasal dari titik acuan 0 meter atau dalam soal adalah lantai. Pada gambar 6 juga menunjukkan siswa tidak mampu menerapkan konsep kekekalan energi mekanik untuk menyelesaikan permasalahan pada soal. Dari pengolahan data jawaban TKR diperoleh $100 \%$ siswa tidak mampu menerapkan konsep kekekalan energi mekanik untuk menyelesaikan permasalahan pada soal. Hal ini terjadi karena siswa masih menganggap bahwa energi kinetik dan energi potensial dimiliki benda secara terpisah. Mereka tidak mampu memahami hubungan konsep energi kinetik, energi potensial, dan energi kinetik benda.

\section{Perubahan Energi}

Pada soal nomor 4 siswa diminta menyebutkan perubahan energi yang terjadi ketika televisi dinyalakan dan soal nomor 5 diambil dari soal TIMMS dimana siswa diberikan kasus lampu yang menggunakan energi listrik sebagai sumbernya. Berdasarkan hasil analisis jawaban TKR awal, diperoleh persentase hambatan epistimologis siswa pada konsep energi potensial sebagai berikut;

TABEL 4. Hambatan awal peserta didik pada konsep kekekalan energi mekanik.

\begin{tabular}{|c|c|c|}
\hline Coding & Hambatan & Persentase TKR Awal \\
\hline 1. & $\begin{array}{l}\text { Keliru menentukan jenis } \\
\text { perubahan energi pada } \\
\text { peristiwa sehari-hari. }\end{array}$ & $66,67 \%$ \\
\hline 2. & $\begin{array}{l}\text { Keliru menentukan jumlah } \\
\text { energi listrik yang digunakan } \\
\text { dibandingkan dengan jumlah } \\
\text { energi cahaya yang dihasilkan } \\
\text { pada lampu. }\end{array}$ & $88,89 \%$ \\
\hline
\end{tabular}

Dari hasil TKR, diketahui bahwa 66,67\% siswa masih keliru menentukan energi yang dihasilkan dari perubahan energi pada peristiwa sehari-hari. 


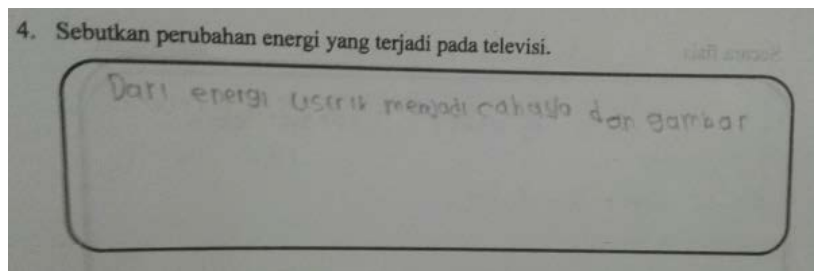

GAMBAR 7. Jawaban siswa pada soal nomor 4.

Gambar 7 siswa menunjukkan kekeliruan siswa dalam menyadari jenis-jenis energi dalam kehidupan sehari-hari, yakni dalam menyadari perubahan energi pada telivisi yang sebenarnya mengubah energi listrik menjadi energi cahaya, energi panas, dan energi bunyi. Namun siswa tersebut hanya mampu menyebutkan energi cahaya dan "energi gambar". Hal ini disebabkan karena siswa tidak memahami arti energi dan tidak menyadari jenis-jenis energi dalam kehidupan sehari-hari.

Pada soal nomor 5 siswa diminta membandingkan jumlah energi listrik yang digunakan dengan jumlah energi cahaya yang dihasilkan. Diketahui $88,89 \%$ siswa tidak dapat menentukan jumlah energi yang digunakan dibandingkan dengan energi yang dihasilkan menggunakan konsep kekekalan energi maupun disipasi energi.

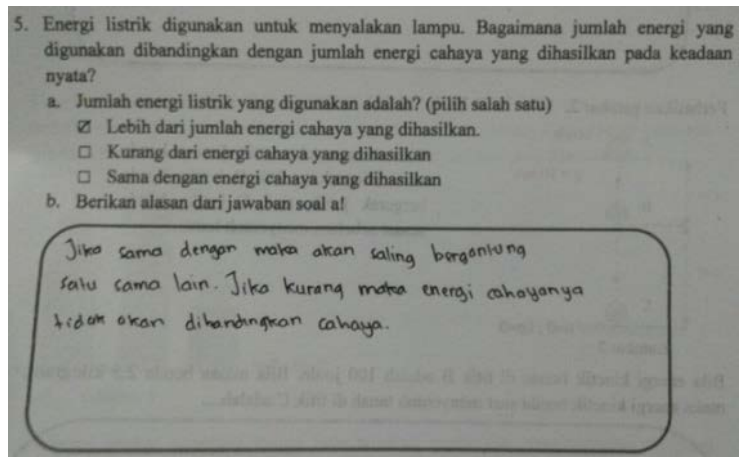

GAMBAR 8. Jawaban siswa pada soal nomor 5 yang masih mengalami hambatan (1).

Gambar 8 menunjukkan siswa masih mengalami hambatan karena gagal menjelaskan mengapa energi listrik yang digunakan lebih dari energi cahaya yang dihasilkan, dimana siswa tersebut tidak paham akan adanya konsep disipasi energi.

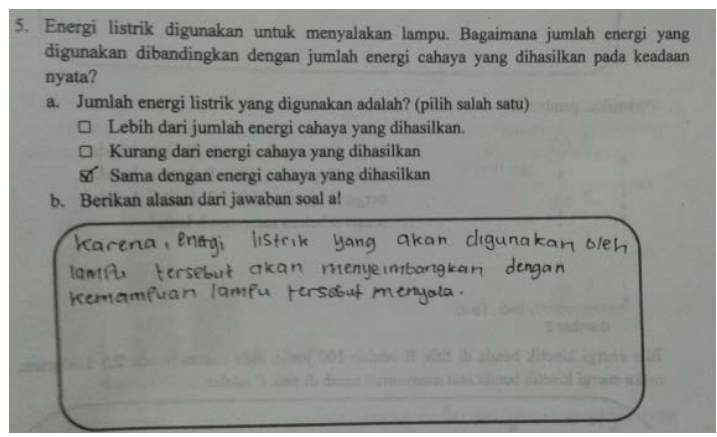

GAMBAR 9. Jawaban siswa pada soal nomor 5 yang masih mengalami hambatan (2).

Gambar 9 menunjukkan siswa tidak mampu menjelaskan mengapa energi listrik yang digunakan sama dengan energi cahaya yang dihasilkan dengan dikaitkan dengan konsep kekekalan energi. Hal tersebut terjadi karena siswa tidak mampu memahami konsep konversi energi pada lampu tersebut dan tidak dapat mengaitkan konsep kekekalan energi dalam kehidupan sehari-hari. 


\section{SIMPULAN}

Berdasarkan hasil yang didapat dari uji TKR awal pada materi energi dan perubahannya dapat disimpulkan bahwa;

a. Pada konsep energi kinetik siswa paling banyak mengalami hambatan dalam menjelaskan hubungan antara kecepatan dan energi kinetik benda, yakni sebanyak 83,33\%.

b. Pada konsep energi potensial siswa paling banyak mengalami hambatan dalam menjelaskan hubungan antara energi potensial dengan ketinggian benda, yakni sebanyak 86,11\%

c. Pada konsep kekekalan energi mekanik siswa paling banyak mengalami hambatan dalam menerapkan persamaan kekekalan energi mekanik pada kasus gerak jatuh bebas, yakni sebesar $100 \%$.

d. Pada konsep perubahan energi siswa paling banyak mengalami hambatan dalam menentukan jumlah energi yang digunakan dibandingkan dengan energi yang dihasilkan pada kasus lampu dengan sumber daya listrik, yakni sebanyak 88,89\%.

Maka, pengajar diharapkan mampu menyusun sebuah desain pembelajaran yang dapat mengantisipasi hambatan-hambatan yang dialami siswa tersebut sehingga siswa dapat mengikuti proses pembelajaran secara efektif dan efesien.

\section{UCAPAN TERIMAKASIH}

Terimakasih kepada pihak-pihak yang telah membantu dalam penyusunan paper ini. Terimakasih kepada Allah SWT, orang tua tercinta Bapak Agus Muhyidin dan Ibu Dede Mardiani. Terimakasih kepada Ibu Heni Rusnayati selaku pembimbing I, Bapak Agus Fany selaku pembimbing II, beserta teman-teman tim DDR Kartika, Hanna, Gita, dan Arif yang telah membantu dalam berdiskusi mengenai analisis dalam paper ini, Terimakasih pula kepada kaka saya tercinta Septi Rachmah Solihah yang telah membantu dan mendukung dalam segala aspek pada proses penyusunan paper ini.

\section{REFERENSI}

[1] Basiran (2012). Faktor yang Mempengaruhi Kesulitan dalam Belajar. Jurnal Edukasi, 7 (1), hlm. 1-18.

[2] Brosseau, G. (2002). Theory of Didactical Simulations in Mathematics. New York: Kluwer Academic Publisher.

[3] Nusantara, Fauzan. (2015). Desain didaktis konsep usaha kelas XI SMA berdasarkan analisis kesulitan belajar siswa. Skripsi, Universitas Pendidikan Indonesia.

[4] Pemerintah Republik Indonesia. (2014). Permendikbud RI Nomor 103 Tahun 2014 tentang Pembelajaran pada Pendidikan Dasar dan Pendidikan Menengah. Jakarta.

[5] Suryadi, Didi. (2010). Penelitian Pembelajaran Matematika Untuk Pembentukan Karakter Bangsa. Seminar Nasional Matematika dan Pendidikan Matematika, hlmn. 1-14.

[6] Wariyono, Sukis. (2009). Mari Belajar Ilmu Alam Sekitar 2 untuk Kelas VIII SMP dan Mts. Jakarta: Pusat Perbukuan Departemen Pendidikan Nasional. 